\title{
The Legal Dilemma and Solutions over the Real Estate Tax Levy
}

\author{
Zhisheng Xue ${ }^{1, *}$ and Fang Liu ${ }^{2}$ \\ ${ }^{1}$ School of Law of Tiangong University, 399, Binshuixidao Xiqing District Tianjin, P.R.C \\ ${ }^{2}$ School of Law of Tiangong University, 399, Binshuixidao Xiqing District Tianjin, P.R.C \\ *Corresponding author. Email: xzs678@126.com
}

\begin{abstract}
At present, there is still controversial in both legislation and practice in terms of real estate levy. Because of real estate tax levy of our country are facing many legal dilemmas, such as, the conditions for tax reform have not been met, the real estate tax itself is not ready, etc. Based on this, the writers analyze the reason for the legal dilemma of real estate tax levy through legislation, principle, collection and management level and others, and put forward the corresponding solution path to ensure the real estate tax levy without a hitch.
\end{abstract}

Keywords: Real estate tax, The principle of quantities-based taxation, Collection and management level.

\section{INTRODUCTION}

Real estate tax is a tax system composed of taxes that are directly related to real estate. The significance of its establishment lies in perfecting the national real estate tax system and accomplishing its real estate policy objectives. On May 18, 2020, the CPC Central Committee officially issued Opinions of the CPC Central Committee and the State Council on Accelerating the Improvement of the System of Socialist Market Economy in a New Era. Among them, on the real estate tax mentioned to promote the real estate tax legislation. Then, the news about the real estate tax legislation intensified, but legislation does not happen overnight, the same levy of real estate tax is also facing numerous difficulties.

\section{REAL ESTATE TAX LEVY IS FACING THE LEGAL DILEMMA}

\subsection{The Conditions for Tax Reform Have not been Met}

Our country is different from the foreign in the real estate system and the land policy regulation. Foreign house property tax system due to its different national conditions, not only is the price of land use right cheaper, but the use period is longer than the domestic, so in possession of property in line with the property tax conditions. In the case of housing purchase in China, the taxpayer has already paid relevant taxes. If the real estate tax is introduced at this time, it is likely to lead to repeated levy of taxes and fees. At this time, it is necessary to deduct the part of repeated levy and reform the tax system. According to the current tax system of our country, it is far from meeting the conditions of real estate tax reform.

\subsection{The Real Estate Tax Itself is not Ready}

Once fully implemented, the real estate tax will have an influence on housing prices to some extent, but whether it works as a brake on housing prices or an increase in housing prices is still controversial. One view is that its appeal to physical products and financial products may have different results because of the tax increase involved. If a tax is imposed on a financial product, there is a high probability that the price of the product will fall. For example, the 530 stamp-tax event. And if the tax is added to physical products, it tends to increase the price. House property taxes are levied on houses, which are physical and can cause prices to rise. Another view is that the introduction of real estate tax may have a certain dampening effect on housing prices, especially in view of the current phenomenon of housing speculation. But if house prices drop sharply, the biggest effect will be on land values. On the one hand, for developers will reduce the confidence to take the land, speculators will also reduce the relevant investment. On the other hand, it would ease the burden 
of home ownership for the non-homeowner, but it would be unwise for the country to quickly lower house price expectations without a major tax boost.

\subsection{It Has a Great Impact on Society and Threatens Social Stability}

For the society, the real estate tax will have a huge impact if it is introduced in a short time. According to the current statistics, more than $60 \%$ of the assets of the people in our country are houses. If the house property tax is introduced in a short time, it will increase the living burden, because the housing mortgage interest itself is equivalent to paying more money for a house. If the real estate tax is added, the burden is self-evident. If the tax begins to implement, it could also trigger unpredictable foreclosures phenomenon, cause instability in credit market and hurt the housing market. at the same time, there are most of the real estate enterprises in our country, the impact on the real estate enterprises is also huge, once a large number of enterprises appear bankruptcy tide, followed by the unemployment rate will increase, affecting social stability.

\section{ANALYSIS OF THE REASONS THAT REAL ESTATE TAX LEVY FACE PREDICAMENT}

\subsection{The Legislative Level is Low, the Legislative Purpose is not Unified}

The low level of real estate tax legislation affects the seriousness, authority and stability of real estate tax legislation. The current law and regulation related to real estate tax in China is only about Interim Regulation of the People's Republic of China on Real Estate Tax. This shows that the real estate tax legislation system of our country is not sound, low level. The real estate related tax laws are only income tax, other related taxes are only temporary regulations.

In addition, a very important reason for the difficulty of real estate tax legislation is that the purpose of real estate tax levy is not unified. There are two main controversies about the purpose of real estate tax levy. One holds that real estate tax levy is intended to serve a local public expenditure project which is the responsibility of the local government for the benefit of the local public. Another view is that the above purpose of levy is difficult to achieve. In my opinion, although it is difficult to realize real estate tax as a tax serving local public projects in the short term, but in the long term, it is only a matter of time for the real estate tax to be levied until the real estate market reaches a real sense of stability.

\subsection{Improper Implementation of Tax Revenue may Violate the Principle of Quantities-based Taxation}

The principle of quantities-based taxation is the principle of determining different tax burdens according to the size of the taxpayer's ability to bear the burden. There is a close relationship between the principle of quantities-based taxation and the implementation of taxation. But in reality, it is often easy to cause unfair situation caused by improper tax implementation. In turn, it violates the principle of volume taxation. For example, homeowners who own different properties may encounter the same tax burden, real estate tax expenditures may impose different tax burdens on households with different incomes.

\subsection{Real Estate Tax Includes Too Much and Leads to Double Taxation}

Real estate tax is a comprehensive concept, is a real estate-related tax system, related to real estate and fees other than taxes throughout the property development, transaction and ownership chain can be included, so the tax is very broad and involves a lot of stakeholders. Therefore, it is easy to cause the unfair phenomenon of double taxation, leading to widespread tax evasion of enterprises in related industries. The real estate tax levy also has a very serious cross-district problem. For the local tax, specific standards are determined by the local authorities themselves, and if there are cross-distric properties at the same time, how to levy the house property tax becomes a problem. In the case of multiple tax consolidation of property tax, the problem of double taxation is easy to appear.

\subsection{The Level of Real Estate Tax Collection and Management is Limited}

\subsubsection{The Registration and Management System of Real Estate Has not been Improved}

Interim Regulation on Real Estate Registration has been announced, there are still many problems in practice. Real estate registration is not well implemented in many places, nor is there a nationwide search for information, lack of clear statistical standards for information. The structure of each registration authority does not make sense and some functions overlap and vacuum phenomena exist. In addition, if you want to start to implement the real estate tax levy, it needs multi-department coordination and cooperation. According to the current social status quo, it is also a big problem of real estate tax levy. 


\subsubsection{Collection and Management Procedures are Complex, the Work of Administrative Organs is Difficult}

The real estate tax levy procedure is not perfect in our country, the work of administrative organs is difficult in practice. In the first place, there has been controversy over the specific measures to impose a property tax. Some people say that according to the number of houses, some people think that it is suggested to levy according to rent or house price. Disputes over how the tax should be levied have led to different prices, it is questionable for the Social distribution and for the development of society to determine which type of taxation applies. In the next place, the scope of taxation is relatively narrow in the property tax pilot reform and the objective of increasing local fiscal revenue has not been achieved. In the end, the complexity of the real estate tax levy procedure makes the work of the management organ more difficult. For instance: different housing according to its property right can be divided for a variety of properties. There are many different factors, such as location, location, orientation and size, which can lead to different house values. To sum up, there are also different types of property taxes which has different levy procedures, which eventually lead to the difficulty of levy by administrative organs.

\section{REAL ESTATE TAX LEVY IS FACING THE DILEMMA SOLUTION PATH}

\subsection{On the Basis of Unified National Legislation, Local Governments Have Formulated Relevant Regulations}

First of all, in accordance with the provisions of Article 8 of the Legislation Law of the People's Republic of China, basic taxation systems shall only be governed by law, such as the institution of taxable items, the determination of tax rates, tax levy and administration, etc. Therefore, real estate tax must be national unified legislation. One is to ensure the unity of real estate tax legislation. House property taxes are local taxes levied nationwide, and such a system that concerns the overall interests of society needs to be legislated nationally in the future. Second, it is helpful to the establishment of the real estate tax law system. As is well known, real estate taxes involve a wide range of tax categories. National unified legislation contributes to the systematization of real estate tax legislation.

Secondly, On the basis of national unified legislation, the author thinks that local governments should also formulate specific regulations. On the one hand, the different levels of economic development in different regions lead to differences in housing prices and residents' income levels; on the other hand, the provisions of unified legislation may be too principled and not specific enough leads to the implementation of the situation is not in place. In conclusion, the formulation of corresponding provisions in various places is to the benefit of specific analysis of specific problems, better implementation of real estate taxes based on actual conditions.

\subsection{Implement House Property Tax Regulations, Follow the Principle of Quantities-based Taxation}

In order to ensure the real estate tax related laws of the correct implementation follow the principle of quantities-based taxation. The writers think the reason mainly from the following two points: First, the levy of real estate tax depends on the tax element which the assessed value of the property, the tax rate, the exemption conditions and the tax preference. Second, do a good job in supervising the levy of real estate tax, ensure that the property tax is levied in a targeted and differentiated manner, guarantee can not only achieve the purpose of levying real estate tax and will not let the taxpayer tax burden capacity is too heavy.

\subsection{Improve the Level of House Property Tax Levy and Administration}

\subsubsection{Improve the Registration and Management System for Real Estate}

Improving the real estate registration management system is an important step to begin to levy real estate tax. Not only all departments in the region should establish tax-related information sharing system, but also tax-related information sharing mechanism between regions should be established, which is the premise for a nationwide property tax. Therefore, the writers suggest carry out real estate census and registration work, do a good job in the comprehensive network of real estate data and information, establish a unified real estate information management platform, protect the legitimate rights and interests of taxpayers.

\subsubsection{Improve the Means of House Property Tax Levy, Enhance the Management Ability of Related Departments}

As a result of our country each area economic development level is not balanced, the authors suggest that the specific real estate tax levy methods and means to delegate power to local which confirm the levying means of real estate tax according to the actual situation of real estate in this area. In addition, the implementation of taxation is inseparable from the execution of relevant departments. The authors suggest scientific regulation of tax law enforcement, for example, intensify the study of regulations knowledge 
of administrative organs, improve the quality of law enforcement personnel and carry out examination of law enforcement on tax, strengthen the accountability system for administrative organs.

\section{CONCLUSION}

To sum up, in order to alleviate the real estate tax facing difficulties, to solve the existing problems, the author proposes suggestions from the following three aspects in this paper. First of all, on the basis of unified national legislation, local governments have formulated relevant regulations. Secondly, implement house property tax regulations, follow the principle of quantities-based taxation. Thirdly, improve the level of house property tax levy and administration.

\section{ACKNOWLEDGMENTS}

This research was financially supported by the Degree and Postgraduate Education Reform Project of Tiangong University "Cultivation and Improvement of Practical Ability of Financial Law for Master of Law" (Project No. Y20170510).

\section{REFERENCES}

[1] $\mathrm{Xu}$ Weihong, Du Jianwei. The legal dilemma of real estate tax levy and its countermeasures [J]. Financial Theory and Practice, 2018,39(01):154-160.

[2] Ye Shan. Consideration of quantitative taxation in the construction of real estate tax law $[\mathrm{J}]$. jurist, 2019(01):57-71+192.

[3] Lin Yuhan. On the reform of real estate tax in the new era from the perspective of law of finance and taxation $[\mathrm{J}]$. Journal of Heihe University, 2020,11(04):40-42+50.

[4] Chen Wanying. On the Path Choice of China's Property Tax System Reform from the Perspective of Rule of Law [J]. Journal of Heilongjiang Institute of Technology, 2019,19(02):103-108.

[5] Liu Juan. The three-dimensional foundation of the real estate tax law $[\mathrm{J}]$. The Northern Review, 2017(05):158-162.

[6] Zhang Xuedan. Our country real estate tax system element design and legislative implementation suggestion [J]. Research on Local Finance, 2019(12):23-27 